\title{
Lumen
}

Selected Proceedings from the Canadian Society for Eighteenth-Century Studies

\section{"Take Care Some Seeds in the Letter": Material and Textual Practices of Seed Exchange in the Long Eighteenth Century}

\section{Maria Zytaruk}

Volume 38, 2019

URI : https://id.erudit.org/iderudit/1059279ar

DOI : https://doi.org/10.7202/1059279ar

Aller au sommaire du numéro

Éditeur(s)

Canadian Society for Eighteenth-Century Studies / Société canadienne d'étude du dix-huitième siècle

ISSN

1209-3696 (imprimé)

1927-8284 (numérique)

Découvrir la revue

Citer cet article

Zytaruk, M. (2019). “Take Care Some Seeds in the Letter”: Material and Textual Practices of Seed Exchange in the Long Eighteenth Century. Lumen, 38,

179-199. https://doi.org/10.7202/1059279ar 


\title{
"Take Care Some Seeds in the Letter": Material and Textual Practices of Seed Exchange in the Long Eighteenth Century
}

\author{
MARIA ZYTARUK \\ University of Calgary
}

On 22 March 1736/37, the Quaker naturalist and linen merchant Peter Collinson composed a letter from London for his correspondent in the American colonies, the botanist John Bartram. Collinson directs Bartram to collect a parcel that Collinson has sent through an intermediary in Philadelphia. The parcel contains a box of seeds and several other letters - two for Bartram and additional letters he is to deliver to Collinson's other colonial correspondents. As a token of his appreciation, Collinson includes in his letter the following botanical gift and instructions:

Inclosed is some seed of a Noble Annual, grows 6 or 7 feet high \& makes a beautifull show with its long bunches of red flowers, but I am afraid it will [be] to Late to venture it this year, However, sow half \& keep the other till next year, it is called the great Oriental Persicaria. I am with Love thy sincere Friend. ${ }^{1}$

A postscript reminds Bartram of the letter's delicate seed enclosure"take Care Some Seeds in the Letter." Even a small quantity of seeds

1. Peter Collinson to John Bartram, March 22, 1736/37, in John Bartram, The Correspondence of John Bartram 1734-77, ed. Edmund Berkeley and Dorothy Smith Berkeley (Gainesville: University Press of Florida, 1992), 43; brackets in the original. For a recent account of Peter Collinson's natural history pursuits, see Jean O'Neill and Elizabeth P. McLean, Peter Collinson and the Eighteenth-Century Natural History Exchange (Philadelphia: American Philosophical Society, 2008).

2. Collinson to Bartram, March 22, 1736/37, in Bartram 44. 
substantially increased the cost of a letter; Collinson advises Bartram that he "[considers] Double postage to have putt $1 / 2$ doz seeds in this Letter." 3 Because loose seeds would undoubtedly spill out of a sealed letter when opened, Collinson likely placed the six precious seeds of the "Oriental Persicaria" first in a folded paper packet [see figures 1 and 2], which he then enclosed in the letter.

We have, in Collinson's letter, a window onto seed exchange as it was practised between private individuals during the long eighteenth century. Conducted alongside the commercial market for plants, such private seed transfers were not without their own tangible costs. They required a social network, an epistolary apparatus, some spare paper for fashioning seed packets, as well as patience and imagination. In the essay that follows, I explore the material and textual practices associated with seed exchange between individuals. While correspondence by Collinson and other eighteenth-century figures with horticultural interests has survived in manuscript form, letters rarely, if ever, still preserve their original seed packets. Once a correspondent in the eighteenth century took receipt of a seed packet, its contents were likely swiftly sowed in the garden or divided further among intimates. If a manuscript letter did preserve its original seed packet for a period of time, once it arrived in an institutional archive or library, its organic matter meant that it was usually disposed of or at least separated from the letter. Thus, while it has been possible to reconstruct some of the dynamics of seed exchange using eighteenth-century correspondence, the precise material features and contexts of "some seeds in the letter" have remained largely out of view. ${ }^{4}$

Where eighteenth-century plant and seed transfer has been treated by scholars, British imperial projects have provided the central framework. The essays in Visions of Empire: Voyages, Botany, and the Representations of Nature (1996) trace how the drive to identify new profitable species for the empire spurred the diffusion of plant material associated with the journeys of Joseph Banks and James Cook. ${ }^{5}$

3. Ibid., 43.

4. Ibid., 44.

5. David Phillip Miller and Peter Hans Reill ed., Visions of Empire: Voyages, Botany, and Representations of Nature (Cambridge: Cambridge University Press, 1996); see especially, David Philip Miller, "Joseph Banks, Empire, and 'Centers of Calculation' in Late Hanoverian London": 21-37; and David Mackay, "Agents of Empire: The 
In Natures in Translation: Romanticism and Colonial Natural History, Alan Bewell expands on a point made earlier by David Philip Miller about the mobility of natural history specimens. For Bewell, the British identity in the eighteenth century and beyond was rooted in the nation's "capacity to mobilize people and things." Taken together, an article by Christopher Parsons and Kathleen Murphy (2012), and an essay by Mark Laird and Karen Bridgman (2014) provide much useful information about the practicalities and rhythms of transporting plant specimens across the Atlantic. ${ }^{7}$ The social and commercial dynamics of botany in the decades around 1800 have been reconstructed recently by Sarah Easterby-Smith. ${ }^{8}$ A. Marples and V.R.M. Pickering have discussed the ways in which botanical objects, specifically those in Hans Sloane's collection, were especially unstable and how organizational systems were developed during the early modern period to manage this knowledge.? Like the above treatments, my essay is concerned with strategies for making fragile botanical materials mobile during the long eighteenth century. I shift the focus, however, from plant transfer as an instrument for, and expression of, imperial power to what might be called the material and literary culture of seed exchange. My

Banksian Collectors and Evaluation of New Lands": 38-57. See also, Londa Schiebinger and Claudia Swan ed., Colonial Botany: Science, Commerce, and Politics in the Early Modern World (Philadelphia: University of Pennsylvania Press, 2005).

6. David Philip Miller's point, drawing on the theories of Bruno Latour, about the mobilization of natural objects occurs in his essay above, "Joseph Banks, Empire, and 'Centers of Calculation," 23; Alan Bewell, Natures in Translation: Romanticism and Colonial Natural History (Baltimore: Johns Hopkins University Press, 2017), 95. For historical accounts of seed transfer during the eighteenth century, see Mark Laird, A Natural History of Gardening, 1650-1800 (New Haven and London: Yale University Press, 2015), especially chapters two and three; and Douglas Chambers, The Planters of the English Landscape Garden: Botany, Trees, and the Georgics (New Haven and London: Yale University Press, 1993).

7. Christopher M. Parsons and Kathleen S. Murphy, "Ecosystems under Sail: Specimen Transport in the Eighteenth-Century French and British Atlantics," Early American Studies 10. 3 (Fall 2012): 503-39; Mark Laird and Karen Bridgman, "American Roots: Techniques of Plant Transportation and Cultivation in the Early Atlantic World," Ways of Making and Knowing: The Material Culture of Empirical Knowledge, ed. Pamela H. Smith, Amy R. W. Meyers, and Harold J. Cook (New York: Bard Graduate Center, 2014): 164-93.

8. Sarah Easterby-Smith, Cultivating Commerce: Cultures of Botany in Britain and France, 1760-1815 (Cambridge: Cambridge University Press, 2018).

9. A. Marples and V.R.M. Pickering, "Exploring Cultures of Collecting in the Early Modern World," Archives of Natural History 43. 1 (2016): 1-20, 9. 
essay also departs from earlier scholarship in its reliance on a fresh set of evidence-a quantity of eighteenth-century seed packets that have survived in British archives. By reading eighteenth-century letters in tandem with extant seed packets and drawing on approaches from material culture studies and book history, I argue that the sociable practice of eighteenth-century seed exchange was implicated in both print and manuscript culture. Constructed from paper "waste," the seed packets partake in discourses of preservation as well as those of loss.

\section{Seeds in Print}

Eighteenth-century print culture stimulated and sustained the appetite for botanical novelties. In addition to published seed catalogues and lists, and such periodicals as Curtis's Botanical Magazine and the Gentleman's Magazine, newspapers advertised the ever-expanding inventories of seedsmen and the import of new species. On 12 February 1702, the London Gazette carried the following notice: "there are lately brought from Italy, choice Tuberose Roots, also several sorts of Double Ranunculos Roots from Flanders, with all sorts of Garden Seeds, Trees, and Plants." "At reasonable rates," these items may be procured from the seedsman Charles Blackwell in Holborn. ${ }^{10}$ We find a notice in the Daily Journal from 24 December 1726 that a "curious Collection of fine Flowers, and Plant Seeds" has been "lately Imported from the West-Indies."ll Interested "gentleman" are invited to call at Daniel Malin's, "next Door to the Three-Tun Tavern, without Bishopsgate." Much later in the century, on 17 February 1791, the World announced the arrival of an annual called, "Iberis Grandiflora; or, New White Rocket Candy Tuft." Recently introduced from France, the plant "appears to be an entire new species" and "seeds of this beautiful Plant [are] to be had in papers of $2 \mathrm{~s}$. $6 \mathrm{~d}$. each, with directions of the mode of culture" from the nursery and seedsmen Grimwood, Hudson, and Barrit on Arlington Street, Piccadilly, and Kensington. ${ }^{12}$ It was thus the same consumer to whom imported textiles and new fashionable household goods appealed who felt the lure of foreign, imported seeds. The sheer variety of seeds available commercially by the late eighteenth

\footnotetext{
10. "Advertisements," London Gazette, February 12, 1702.

11. "To Be Sold," Daily Journal, December 24, 1726.

12. "New Annual Flower," World, February 17, 1791.
} 
century is striking. ${ }^{13}$ To take just one point of comparison: the catalogue of seeds on offer by local London seedsmen, published in the 1688 edition of John Worlidge's Systema Horti-culturae, lists two species of mimosa: the "Sensible Plant" and the "Humble Plant." By the end of the eighteenth century, according to the published catalogue for the seedsmen Gordon, Dermer, and Company, no fewer than nineteen varieties were represented in the seed stock of this one business in London's Fenchurch Street. ${ }^{14}$ Through catalogues and advertisements, then, both the availability and desirability of novel seeds were communicated.

The medium of print served an additional function in the eighteenth-century seed trade. As Malcolm Thick established some time ago, the seedsman's trade was always a precarious one. Seeds might fail because they were improperly sown or because of poor soil or harsh weather. Regardless of whether or not the seedsman was to blame, as early as the sixteenth century seed merchants had a reputation for dishonesty. ${ }^{15}$ Even after the seed business became a less itinerant and disorganized trade, seedsmen continued to be known as proverbial cheats. Thus, well into the eighteenth century, we find seedsmen exploiting the medium of print to establish, or to maintain, their reputations. When the firm Malcolm and Son removed from Kennington to new premises in Surrey in May 1789, the business bolstered its reputation by advertising itself in the World as "Nurserymen and Seedsmen to the Prince of Wales and Duke of York"; customers were assured that "all orders for Trees, Plants, and Seeds [would] be punctually executed and the favour most gratefully acknowledged."16 In July 1798, the seedsman Robert Fair informed "his Friends and the Public" that he had taken a shop in Southwark, "where he hope[d] for a continuance of their favours, as they may depend upon being served

13. On the new and exotic goods marketed to eighteenth-century consumers, see Maxine Berg, Luxury and Pleasure in Eighteenth-Century Britain (Oxford: Oxford University Press, 2005).

14. John Worlidge, Systema horti-culturae, or, The art of gardening in three books, 3rd ed. (1688), 275; Gordon, Dermer, and Co., A Catalogue of Forest Trees, Flowering Shrubs, Plants, Flower-Roots and Seeds (London,1795), 93-94.

15. Malcolm Thick, "Garden Seeds in England before the Late Eighteenth Century - II. The Trade in Seeds to 1760," Agricultural History Review 38 (1991): $105-16,106-7,114$.

16. World, May o1, 1789. 
with genuine Seeds upon the most reasonable terms." ${ }^{\prime 7}$ At all times, seedsmen appealed to their customers' desire to secure true seeds at good prices. In January 1742, the former tailor and draper, now turned seedsman, Robert Claxton advertised in the Norwich Gazette that he, "hath lately been in the BEAN Country, and has bought a large Stock of WINDSOR BEANS, extraordinarily good, which he will sell as Cheap as any other Person in Norwich does SANDWICH." ${ }^{18}$ Claxton offers wholesale rates for the Windsor beans. A recurring notice that appeared in issues of the Collection for the Improvement of Husbandry and Trade at the close of the seventeenth century was placed by an individual seeking a share in the profits by acting as an intermediary or broker between London seedsman and potential customers: "If any in the Country will send to me for Seeds, I know of a Seedsman [who] will furnish with those are purely good, and at as cheap Rates as they can reasonably be afforded." 19 In any case, one need not have relied on such brokers, for, by the eighteenth century, a number of seeds shops had mail-order options: N. Swinden's business on Hyde Park Corner allowed customers to have their orders delivered to local coffee-houses or other locations of their choosing. ${ }^{20}$

In this section of the essay, I have traced some of the ways in which print culture served as an apparatus for the commercial seed trade. The proliferation of commercial seed businesses and their visibility in print suggest that the availability of seeds of foreign or exotic species continued to increase during the eighteenth century, and that more than one option existed for purchasing such seeds (established businesses, mailorder systems, brokers, "pop-up" sales). Trust in the commercial seedsman remained a concern, however. As we will see in the next section of this essay, although a variety of seeds were stocked in London shops

17. “To Seedsmen, Nurserymen, Gardiners, \&c.," Star, July 19, 1789.

18. "Advertisements," Norwich Gazette, January o9, 1742.

19. "Advertisements," A Collection for the Improvement of Husbandry and Trade, March 20, 1696; this call for seeds ran until at least February 20,1697. For the cultivation of Sandwich varieties of garden seeds in the mid sixteenth century and beyond, see Malcolm Thick, "Garden Seeds in England before the Late Eighteenth Century - I. Seed Growing,” Agricultural History Review 38 (1990): 58-71, 61.

20. Swinden's business is described in vol. 2, The Eighteenth Century, of Blanche Henrey, British Botanical and Horticultural Literature (Oxford: Oxford University Press, 1975), 376. 
by the eighteenth century, private seed exchange continued apace and offered an alternative for individuals seeking rare and viable seeds.

\section{Seeds and the Familiar Letter}

A postscript to a letter that Collinson sends Bartram on 1 February 1738/39 captures the affective dimension of private seed exchange: "I Long the arrival of the Ship with the Seeds. I wish they are not much spoilt."2l Eighteenth-century correspondence about botanical matters, and about seeds in particular, registers anxieties about seeds in transit, their viability, and their novelty for the recipient. Not strictly a letter of business, a letter of intelligence, or a letter of advice, at times the seedsbegging letter resembled all these epistolary forms. ${ }^{22}$ These letters pulse with curiosity about unfamiliar species and detail arrangements for the safe conveyance of seeds. Lurking in the background of the seeds-begging letter is the figure of the dishonest commercial seedsman. As the gentleman John Evelyn puts it grimly in a letter to a correspondent in Barbados from September 1681: "there is no trust in our mercenarie Seedes-men of London, for any thing." ${ }^{23}$ A few decades later, in July 1736, one of Collinson's correspondents in Virginia rehearses the same complaint: "I know not how it happens; the seeds in generall we have from England very often never come up; I believe it is often the faults of the seeds men."24 If transactions with the commercial seedsman were inherently risky, and if his stock did not always include the most novel seeds, the familiar letter provided the necessary apparatus for circulating seeds among individuals. In contrast to the more impersonal transactions associated with commercial seeds shops, private seed exchange relied on relationships of trust and reciprocity

21. Collinson to Bartram, 1 February, 1738/39, in Bartram, 110.

22. Some of these categories overlapped in practice, as Eve Tavor Bannet shows in Empire of Letters: Letter Manuals and Transatlantic Correspondence, 1688-1820 (Cambridge: Cambridge University Press, 2005), 57-58.

23. John Evelyn to William London, September 27, 1681, in The Letterbooks of John Evelyn, vol. 2, ed. Douglas D.C. Chambers and David Galbraith (Toronto: University of Toronto Press, 2014), 667.

24. John Custis to Collinson, [29 July], 1736, in Peter Collinson and John Custis, Brothers of the Spade: Correspondence of Peter Collinson, of London, and of John Custis, of Williamsburg, Virginia, 1734-46 (Worchester MA: American Antiquarian Society, 1949), 50. 
cultivated through correspondence. ${ }^{25}$ Whereas "pop-up" sales of newly imported seeds and even the wares of established seedsmen could be suspect, the provenance of seeds exchanged between intimates was less in doubt. Indeed, future seed exchanges depended on the viability of previously transmitted seeds. Codes of epistolary civility, then, rather than commercial dynamics, govern in such letters.

Letters that record private seed exchanges turn on whether the seeds one has sent are "acceptable." A pliable term, acceptable is used by correspondents to designate seeds as rare, desirable, and genuine. A letter from December 1735, composed by Collinson and addressed to the Virginia planter John Custis, is typical of the transatlantic seedsbegging letter. A polite request, based on information from a knowledgeable acquaintance, is made for the seeds of a non-native species to England: "Mr. Catesby tells Mee there is a very pretty plant that $\mathrm{He}$ calls a sorrell Tree that Grows between Williamsburgh \& York. Some seed will be Acceptable." ${ }^{26}$ Collinson is likewise explicit to Bartram in a letter from 17 February $1737 / 39$ about what kinds of seeds will find favour: "Seeds of all the Evergreen Tribe will be Acceptable." 27 In a letter addressed to the Antigua physician J. Slingsby Cressy, Bartram uses the same language to describe unusual seeds: "I received thy kind letter of May ye 26 with ye specimens seeds \& other curiosities all which is very acceptable for I love anything that is curious in any branch of nature." 28 Bartram also exchanged botanical materials with Philip Miller, the chief gardener of the Chelsea Physic Garden. Following up on the status of one of his shipments to Bartram, Miller writes the following: "I shall be glad to know if any of the seeds which I sent you last year have grown and if they were agreable, because I can supply you with many other sorts if I know they are acceptable." ${ }^{29}$ Here, the viability of seeds is what makes them acceptable. A rather freighted term, acceptable in the context of seed exchange could mean seeds of

25. In addition to conducting private seed exchanges, Collinson and Bartram also operated a commercial subscription business for boxes of seeds prepared by Bartram. For Bartram's seed boxes, see Joel T. Fry, "Inside the Box: John Bartram and the Science and Commerce of the Transatlantic Plant Trade," in Ways of Making and Knowing: 194-220.

26. Collinson to Custis, December 15, 1735, in Brothers of the Spade, $4^{8}$.

27. Collinson to Bartram, February 17, 1737/38, in Bartram, 85 .

28. Bartram to J. Slingsby Cressy, July 24, 1740, in Bartram, 138.

29. Philip Miller to Bartram, February 15, 1757, in Bartram, 420. 
non-native species, seeds of unfamiliar plants, and seeds which had produced "agreeable" or pleasing plants.

Another feature which might make seeds acceptable to their recipient was their provenance. Because seeds were inscrutable objects from the outside, a chain of custody enhanced their value. Of course, whereas the provenance of a book can be discerned by a copy's book plates, a library stamp, an owner's signature, marginalia, and the like, establishing the provenance of seeds had to be taken on faith. Miller's letter above to Bartram points to the ways in which seeds from botanic gardens entered the circuits of private seed exchange. Seeds associated with such famous botanic gardens carried with them a particularly desirable provenance. With a measure of satisfaction, Collinson reports in a letter from December 1736, addressed to John Custis, that he has "Just now rec'd from the professor of the Botanic Garden att Petersburgh the Inclosed seeds. They appear to Mee very Fresh." 30 That the viability of seeds-or their perceived viability-was tied to their provenance was understood by the naturalist and collector William Courten (1642-1702), who acted as an intermediary between John Locke and Pierre Magnol, the director of the Royal Botanic Garden of Montpellier. ${ }^{31}$ In May 1681, Courten delivered seeds sent from Locke to Magnol. ${ }^{32}$ Courten reports in October of that year that in transit for Locke are seeds from Magnol, "with some few that I have got of a friend that tooke the paines to gather them himself in the Pyrenean mountaines." 33 Courten grasped the dynamics of private seed exchange. Even if seeds were not linked to a celebrated botanic garden and simply "gathered by a friend" (or by a friend of a friend), within this alternative economy of exchange, they assumed a value greater than if sold by a seed merchant. ${ }^{34}$ In many cases, seeds were simply favours exchanged between intimates. A letter from 20 December 1760 addressed to Bartram from Martha Logan (1704-79), the Charleston botanist and nurserywoman, illustrates how

30. Collinson to Custis, December 4, 1736, in Peter Collinson,"Forget Not Mee ६ My Garden...": Selected Letters 1725-68 of Peter Collinson, F.R.S, ed. Alan W. Armstrong (Philadelphia: American Philosophical Society, 2002), 54.

31. Courten used as an alias William Charleton.

32. Courten to John Locke, May 27, 1681, in The Correspondence of John Locke, vol. 2, ed. E. S. de Beer (Oxford: Clarendon Press, 1976), 399.

33. Courten to Locke, October 14, 1681, ibid., 448.

34. Ibid. 
friendly reciprocity structured private seed exchange. After thanking Bartram for a previous gift of seeds, Logan makes her not inconsiderable request:

I doubt not you have many things which I should be glad of as I am particularly fond of Double flowering \& if you could send me a fue Seeds of white Stock gilly flowers \& yellow Wall flowers which would produce the Double flowers or any of the Sweet or other Pease of the Like kinds they would be much Esteemed. ${ }^{35}$

To encourage a favourable response from Bartram, Logan reminds him of her earlier gift of seeds and of the visit from which they issued: "The seeds I sent you, by the name of Virginia Stock, was of the same little flower you so much admired in my garden." ${ }^{36}$ Leaving nothing to chance, Logan adds the following: "I hope they have succeeded with you; but have again sent a few more, for fear of any accidents." ${ }^{37}$ Who incurred what might be called the first "seed debt" in such epistolary chains is often difficult determine; obligations and expectations bleed into one another as each correspondent seeks to transmit acceptable seeds.

As the textual apparatus for private seed exchange, the familiar letter established whether seeds were acceptable and had the right provenance. The letters that initiated seed exchanges performed other, more imaginative functions as well. Scholars such as Malcolm Thick and Sarah Easterby-Smith have rightly situated the desire for novel seeds within the context of eighteenth-century consumerism. ${ }^{38}$ Certainly, the demand for novel seeds was elastic. Writing to the German botanist Christopher Jacob Trew from London in November 1752, Collinson displays the unbounded appetite for variety characteristic of eighteenth-century consumerism: "I very much desire seed of White, Red \& yellow Flowers Pulsatilla. The Blew Flower grows spontaneously Here in England, but Wee have no other Colours." ${ }^{39}$ Such lines make clear that, just as the eighteenth-century consumer hankered after new patterns in printed cottons and neckerchiefs, for

35. Martha Logan to Bartram, December 20, 1760, in Bartram, 500.

36. Ibid.

37. Ibid.

38. See Thick, "Garden seeds - II"; and Easterby-Smith, especially chapter 2, "Science, Commerce and Culture": 50-76.

39. Collinson to Christopher Trew, November 15, 1752, in Collinson, 162. 
those with elevated "botanical palates," one domestic variety of a plant simply would not do. ${ }^{40}$ An important difference exists, though, between seeds and the objects we associate with eighteenth-century consumerism. Most consumer goods-mirrors, shoe buckles, tea trays, and the like-were encountered in the shop, already fashioned and ready for use by the customer. The products of seeds, however, existed only in potentia. While some seeds, such as the striking red and black seeds of the jequirity bean, may have offered some immediate aesthetic pleasure, most seeds were unremarkable. It was the familiar letter that filled in the space between the seed with the dull exterior and the vibrant botanical production that might eventually issue from it. In a letter from February 1735, Collinson advises Bartram:

In the Little Box that the Insects Came In are some Seeds. The China Aster...is the Noblest \& finest Plant thee ever saw of that Tribe. It was Sent by the Jesuits from China to France \& from thence to us. It is an Annuall. Sow it in Rich Mould Immediately....It makes a glorious Autumn flower. There is White \& purple in the Seeds. ${ }^{41}$

Even before Bartram has sown the seeds of the aster, Collinson has brought them to life in vivid colour. There is always a need for description in seed exchange.

The practicalities of seed exchange meant that pleasure was necessarily deferred; only when a seed was sown successfully would the recipient experience what his correspondent had promised in writing. Marking time and feeding hopes, the familiar letter cultivated patience in its addressee. To Henrietta Maria Goldsborough, Collinson writes the following: "Amongst those Inclosed Seeds you will find Some Pyracantha or Evergreen Thorn which in Flower \& Berry make a fine Show, but as this rarely comes up untill next year it must be sowed where it must not be disturbed." ${ }^{\prime 2}$ When language will not suffice to communicate the beauty of a plant, Collinson includes with his gifts of seeds a visual rendering. Promising to shortly send Trew some "Fresh Seed \& the Seed Vessell of the Coroladendron Carolineanum," Collinson writes, "as the

40. For the consumer appetite for textiles and other eighteenth-century fashions, see John Styles, The Dress of the People: Everyday Fashion in Eighteenth-Century England (New Haven: Yale University Press, 2007).

41. Collinson to Bartram, February 12, 1735, in Collinson, 29.

42. Collinson to Henrietta Goldsborough, February 1, 1764, in ibid., 253. 
plant is rare \& scarse \& in very few Gardens, I will send you a painting, done by Van Haysens Brother that you may compare with Ehrets \& Catesbys." ${ }^{\prime 3}$ Manuscript, print, and visual culture converge in this seed letter. By sending an image of the Carolina plant, Collinson provides Trew with a surrogate for the rare species; it would be some time before Trew might encounter the plant first-hand in his own garden.

Although some relationships may have wilted under the pressure to provide rare and viable seeds, the intimacy created in epistolary space, which facilitated such private exchanges, stood in stark contrast to the transactions with "mercernary" and unreliable London seedsmen. In a famous passage from one of Collinson's letters, the Quaker linen draper reflects on his long-standing participation in private seed exchange. He is happy to share seeds of the "yoppon" (Carolina Tea tree) and of the persimmon sent to him by Custis because:

here is no Greater pleasure then to be Communicative \& oblige others. It is Laying an obligation \& I seldome fail of Returns for Wee Brothers of the Spade find it very necessary to share amongst us the seeds that come annually from Abroad. It not only preserves a Friendly Society but secures our Collections, for if one does not raise a seed perhaps another does \& if one Looses a plant another can Supply him. ${ }^{44}$

The fraternity of private seed transfer and the ways in which it spreads out the risk associated with cultivating rare plants are, for Collinson, worth its pains. The manuscript letter has emerged, in this section of the essay, as the key instrument for communicating desiderata, acknowledging the receipt of seeds, authenticating the provenance of seeds, and imparting sowing instructions. To enhance the desirability of the seeds transmitted, and to quell any impatience on the part of the recipient, letters helped the addressee to imagine the seeds coming to life in the garden.

\section{Paper Seed Packets}

Thus far in the essay, I have explored the presence of seeds in eighteenth-century print culture and have made the case for the manuscript letter as the textual apparatus for private seed exchange. In the

43. Collinson to Trew, January 18, 1753, in ibid., 163-64.

44. Collinson to Custis, December 15, 1735, in Collinson, 37. 
final section of this essay, I wish to turn to the paper seed packets used to transmit and to preserve seeds. ${ }^{45}$ Scattered among the letters of eighteenth-century individuals who practiced seed exchange are references to such paper packets. According to Evelyn, writing to Samuel Pepys in September 1686, "seedes are best preserv'd in papers: their names written on them and put in a box."46 A letter addressed by Bartram to the German botanist Johann Dillenius refers to the "severall kinds of seeds wraped up in perticular papers" that he has sent his friend.$^{47}$ In a letter from January $173^{8}$, Collinson tells Bartram that "In the Brown paper are pines \& Firr Seeds from Muscovy." ${ }^{\prime 4}$ Other letters from Collinson refer to "a paper pcell of Seeds" and to a "pacquet of Seeds" that he has sent Bartram. ${ }^{49}$ While these specific seed packets seem not to have survived-likely because their contents were sown right away in the garden and their paper enclosures recycled or discarded-the Natural History Museum of London and the Linnean Society of London do hold among their collections a quantity of eighteenth-century seed packets. Some time ago, Joan Thirsk and James Deetz urged us to pay attention to the "small things"-pins, stockings, pottery-that figured so centrally in early modern British and early American life but that had hitherto escaped the notice of scholars. ${ }^{50}$ More recently, Sarah Pennell and Jenny McKenney have taken up the call to "remember" such seemingly ordinary objects as the pots and pans in the early modern kitchen and women's thimbles in the eighteenth century. ${ }^{51}$ Such scholarship entails putting material

45. As Laird and Bridgman note, seeds were also packaged for transport in boxes, canisters, gourds, textile swatches, and a variety of bags, "American Roots," 171-74.

46. For this letter, the original of which is now lost, see Samuel Pepys and John Evelyn, Particular Friends: The Correspondence of Samuel Pepys and John Evelyn, ed. Guy de la Bédoyère (Suffolk: Boydell Press, 1997), 171.

47. Bartram to Johann Dillenius, [1738, 1739], in Bartram, 107.

48. Collinson to Bartram, 26 January 1738 , in ibid., 109.

49. Collinson to Bartram, February 25,1760, in ibid., 483; Collinson to Bartram, February 10, 1760, in ibid., 480.

50. Joan Thirsk, Economic Policy and Projects: The Development of a Consumer Society in Early Modern England (Oxford: Clarendon Press, 1978); James Deetz, In Small Things Forgotten: An Archaeology of Early American Life (New York: Anchor Books, 1996).

51. Sarah Pennell, The Birth of the English Kitchen, 1600-1850 (London: Bloomsbury, 2016); Sarah Pennell, "Mundane Materiality, or, Should Small things Still Be Forgotten?: Material Culture, Micro-Histories, and the Problem of Scale," History and Material Culture: A Student's Guide to Approaching Alternative Sources, 
objects at the centre of one's inquiry and permitting these to shape one's research questions. ${ }^{52}$ Placing the seed packets at the centre of this final section of the essay, I attempt to bridge the gap that exists now between a manuscript letter by Collinson and the missing seeds it once contained. This object-centred approach to eighteenth-century seed exchange brings into sharper focus Collinson's phrase, "take Care Some Seeds in the Letter." One finds in these packets not only fresh examples of how nature was made "mobile," to use David Miller and Alan Bewell's language, but also of the ways in which these seed packets straddled print and manuscript culture.

Although the majority of the extant seed packets are minimally inscribed on their outside, what information is set down is instructive. Not surprisingly, many packets are associated with the voyages of Joseph Banks and with Botany Bay; packets at the Linnean Society preserve seeds of the camphor tree and of the piqueria plant. ${ }^{53}$ The sociability of seed exchange-the ways in which garden visits and social ties resulted in seed transfers-is evident in other packets. Some are labelled "Mr. Crowe's garden 1802" and "Mrs. Corrie." 54 Other packets document the provenance, discussed earlier in this essay, of seeds associated with famous gardens. The Royal Botanic Garden at Kew, the Chelsea Physic Garden, the Botanic Garden at Calcutta, and the site of Collinson's own garden, Mill Hill, are represented among extant eighteenth-century seed packets. ${ }^{55}$ At times, the inscriptions on the packets are exceedingly compact. One packet reads "to keepMorinda?" (seeds, perhaps, of the tropical evergreen) and another is inscribed with only the word "Beans." 56

In the eighteenth century, when a letter was written on a sheet of paper, which was then folded to create its own envelope and sealed,

ed. Karen Harvey (London: Routledge, 2009): 173-91; Jenny McKenney, “That 'Bossy Shield': Money, Sex, Sentiment, and the Thimble," Lumen 34 (2015): 1-23.

52. For an account and demonstration of an object-centred approach to material culture, see Adrienne D. Hood, "Material Culture: The Object," History Beyond the Text: A Student's Guide to Approaching Alternative Sources. ed. Sarah Barber and Corinna M. Peniston-Bird (London: Routledge, 2009), 176-98.

53. See, for example, Linnean Society (hereafter LS), 137 (J) and 252 (J).

54. LS, $88(\mathrm{~J})$ and $465(\mathrm{~J})$.

55. Unnumbered seed packets at the Natural History Museum of London (General Herbarium) and $\mathrm{LS}_{409}(\mathrm{~J})$.

56. LS, $396(\mathrm{~J})$ and $120(\mathrm{~J})$. 


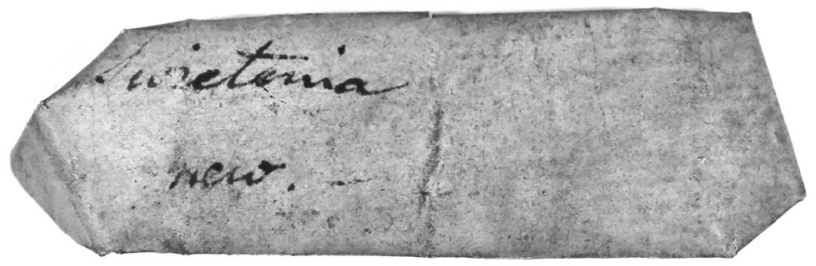

Figure 1. An example of an eighteenth-century seed packet. Seed packet of "Swietenia new" (recto), 272 (J), Carpological Collection, Linnean Society, with permission of the Linnean Society of London.

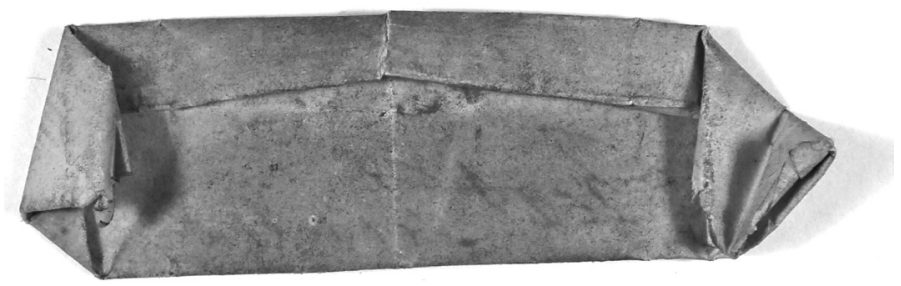

Figure 2. "Swietenia" seed packet (verso), 272 (J), Carpological Collection, Linnean Society, with permission of the Linnean Society of London.

the paper seed packets under consideration needed to be small and flat enough to fit within the letter. ${ }^{57}$ The example shown in Figure 1 is typical of the approximately 8-10 centimetre length of such packets. We know already from Collinson's letter to Bartram (March 22 1736/37), cited earlier in this essay, that adding a seed packet to a letter could double its postage. That Collinson recognizes well the cost and scarcity of paper during the eighteenth century is clear when, in 1734, he sends Bartram a "parcel of Wast paper which will Serve to wrap up seeds \&c. and there is Two Quires of Brown \& one of Whited Brown paper which I propose for this use \& purpose." 58 The latter sheets were included so that Bartram could make voucher specimens for his seeds. What items made up the "Wast paper" used for constructing seed packets? The paper recycled for the packet in Figures 1 and 2 to preserve the winged seeds of the new "swietenia" is a grocer's bill annotated with

57. For the letter-writing process during this period, see Susan E. Whyman, The Pen and the People: English Letter Writers 1660-180o (Oxford: Oxford University Press, 2009), 19-22.

58. Collinson to Bartram, January 24, 1734, in Collinson, 11. 


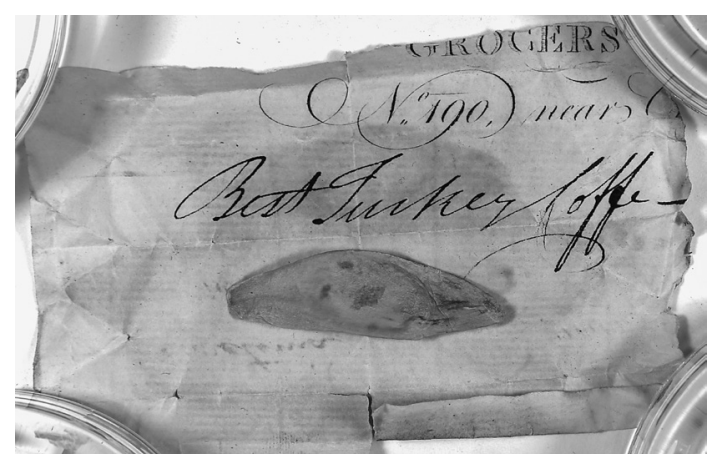

Figure 3. "Swietenia" seed packet (open), 272 (J), Carpological Collection, Linnean Society, with permission of the Linnean Society of London.

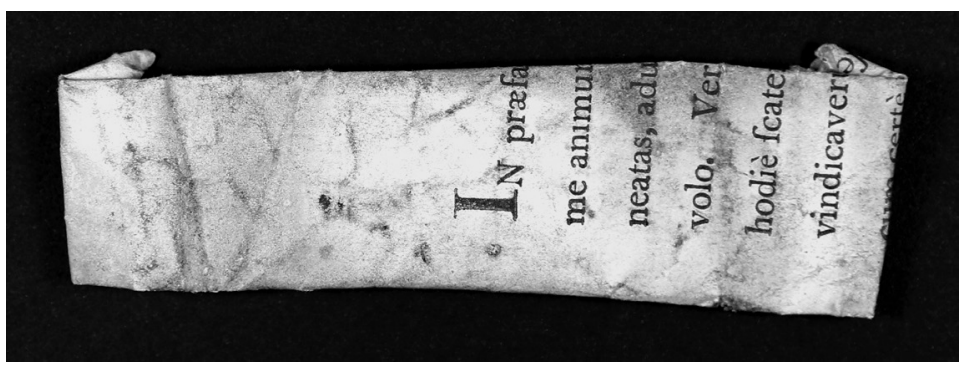

Figure 4. Seed packet made from an eighteenth-century botanical periodical, 412 (J), Carpological Collection, Linnean Society, with permission of the Linnean Society of London.

"Best Turkey Coffee" (figure 3). ${ }^{59}$ The Linnean Society also holds an example of a seed packet made from a page of an eighteenth-century botanical periodical (figures 4 and 5). Also preserved in its archives is a seed enclosure made from a page of a 1790 sermon (figures 6, 7, 8). In this case, the page from the sermon serves as an outer wrapper for a smaller internal seed packet. Pages from a 1794 issue of The True Briton and from the Gazetteer and New Daily Advertiser found new life as seed packets. ${ }^{60}$ Among the seed packets at the Natural History Museum is one made from an advertisement for an "improvable" freehold estate near Covent Garden (figure 9). It is not only printed waste that was recycled to make up seed packets. Hand-written documents

59. LS, $272(\mathrm{~J})$.

6o. LS, $171(\mathrm{~J})$ and $498(\mathrm{~J})$. 


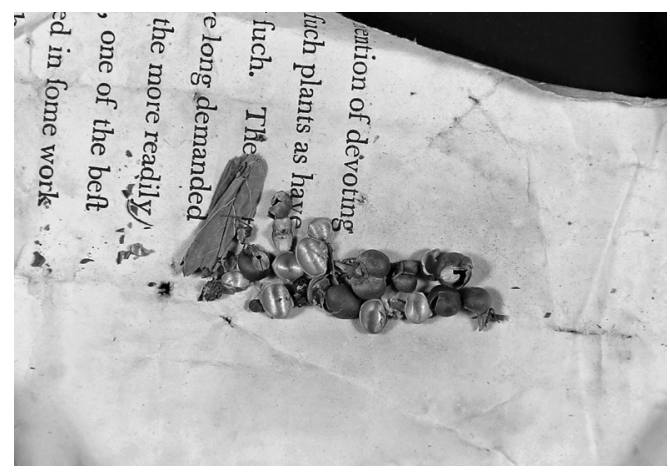

Figure 5. Seed packet made from an eighteenth-century botanical periodical (open), 412 (J), Carpological Collection, Linnean Society, with permission of the Linnean Society of London.

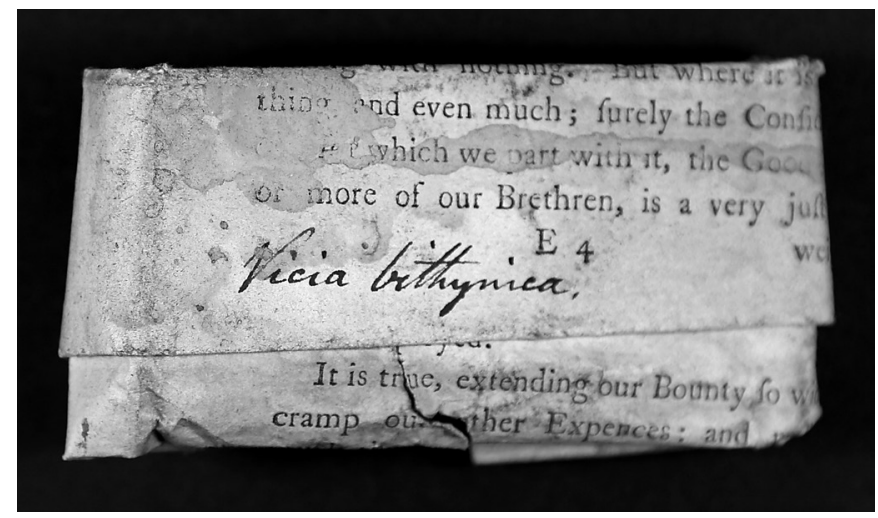

Figure 6. Seed packet made from 1790 sermon (recto), 490 (J) Carpological Collection, Linnean Society, with permission of the Linnean Society of London.

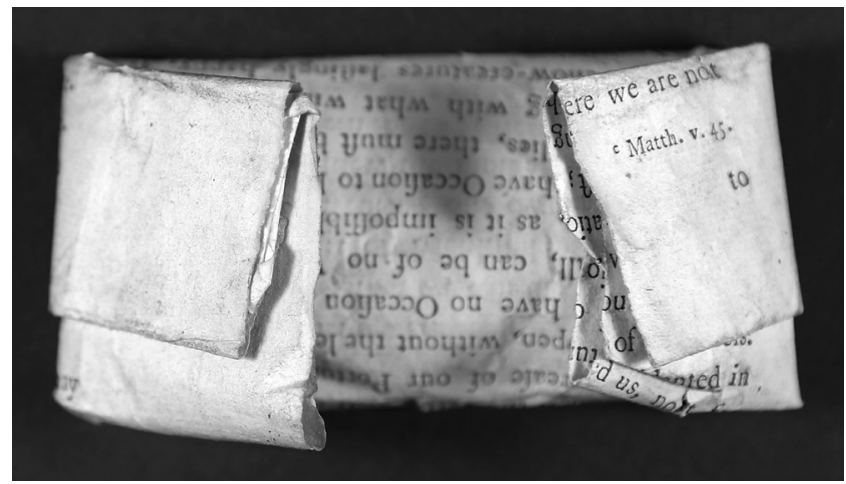

Figure 7. Seed packet made from 1790 sermon (verso), 490 (J) Carpological Collection, Linnean Society, with permission of the Linnean Society of London. 
196 Maria Zytaruk

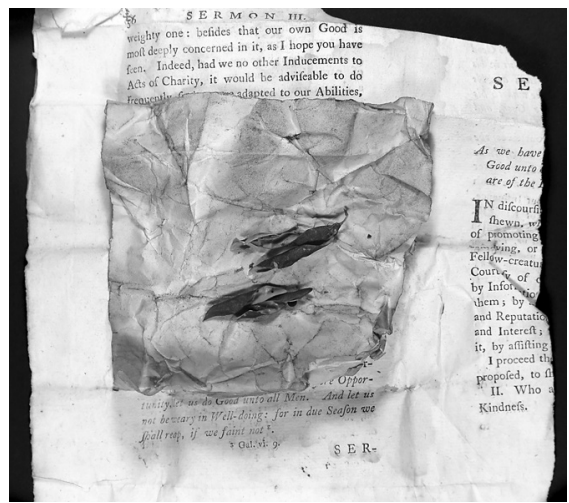

Figure 8. Interior of seed packet made from 1790 sermon (verso) with inner packet, 490 (J) Carpological Collection, Linnean Society, with permission of the Linnean Society of London.

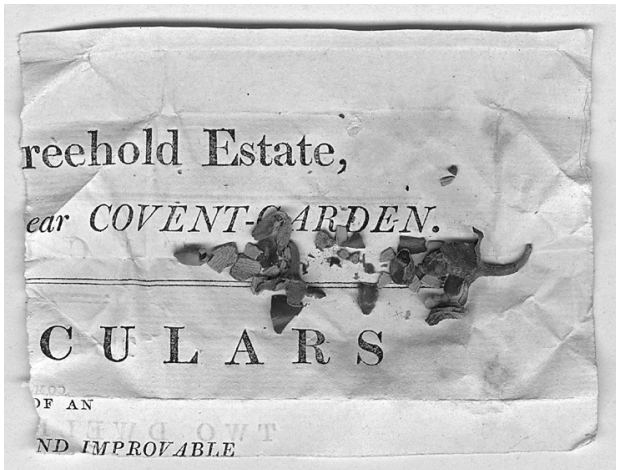

Figure 9. Seed packet made from advertisement for Covent Garden estate, General Herbarium, the Natural History Museum, London (c) The Trustees of the Natural History Museum, London.

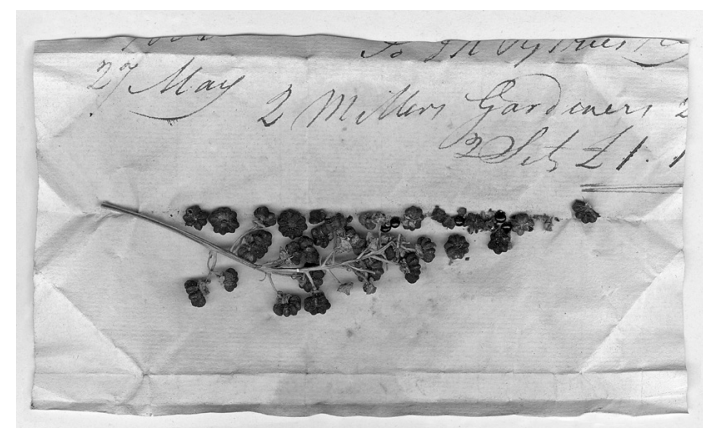

Figure 10. Seed packet made from manuscript document noting purchase of Philip Miller's Gardeners Dictionary, General Herbarium, the Natural History Museum, London @ The Trustees of the Natural History Museum, London. 


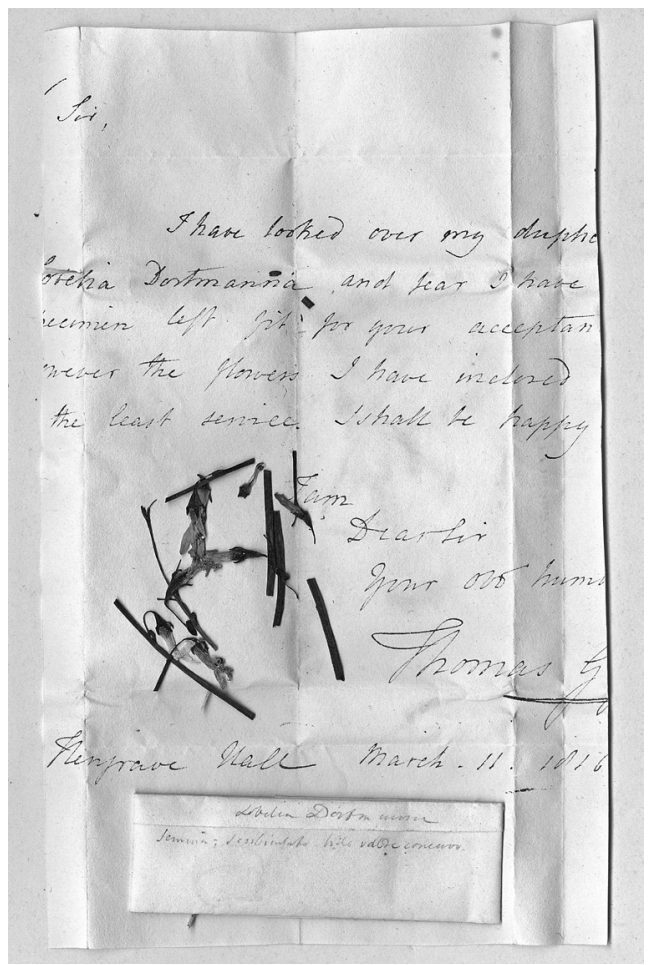

Figure 11. Seed packet for the "lobelia," made from manuscript letter, General Herbarium, the Natural History Museum, London (C) The Trustees of the Natural History Museum, London.

were also repurposed. Two particularly resonant examples are found among the Natural History Museum's collections. A slip of paper recording the purchase of Miller's Gardeners Dictionary is made into a seed packet (figure 10). Incoming correspondence, drafts of letters, and copy letters were similarly re-purposed. In one instance, a fragment of a manuscript letter, which discusses duplicate herbarium specimens of the "lobelia," encloses plant material as well as a smaller seed packet (figure 11).

As we probe more closely the materials from which these seed packets were fashioned, we find a surprising circularity. The very print items used to advertise botanical novelties and the very manuscript letters used to initiate seed exchanges became, themselves, seed packets. Leah Price and others have pressed us to attend to non-reading uses of books-books used as containers and as doorstops. Leslie 
Howsam, in her call for a more integrated history of the book, asks the crucial question: "Can we find a way to recognize the bookishness of things that we do not initially recognize as books?"61 While neither Price nor Howsam had in mind eighteenth-century seed exchange as they pondered more expansive and nuanced approaches to book history, seeds and books do converge in these packets. If the act of writing a letter was sometimes an intimate one in the eighteenth century, the process of carefully folding paper waste to make a seed packet, and placing this enclosure within a hand-written letter sealed with wax gives us a fresh context for thinking about the survival of manuscript culture in the period. The desire for new seeds was, as we have seen, excited by newspaper advertisements and by the lists of plants published by nurserymen in the eighteenth century. The sheets of eighteenth-century newspapers and of periodicals devoted to botany were, themselves, pressed into service as seed packets. Seeds circulated through eighteenth-century print and manuscript culture, then, in both figurative and material ways. Examining all the scraps of letters and of printed eighteenth-century matter which enclosed seeds, one might view these paper seed packets as de-constructed books, put back into circulation again. Of course, it was not unusual during the eighteenth century for paper waste to be re-used by the baker and the fishmonger as wrappers, and as literal waste paper in the privy. But the survival of such printed and manuscript matter as seed packets has more in common with the re-use of paper and vellum waste by binders during the early modern period. As hand-press books decay today in libraries, fragments of medieval manuscripts can be seen peeping out of their bindings. What sets apart seed packets from these other case studies is the organic material they preserve and the potential of their contents to change shape again. Some seeds, such as those of the sacred lotus, have been known to germinate after astonishing periods of time. ${ }^{62}$ While both the materials from which the packets were fashioned and the tiny seeds they enclosed may have been considered

61. Leah Price, How To Do Things with Books in Victorian Britain (Princeton: Princeton University Press, 2012), 12-15; Leslie Howsam, Old Books and New Histories: An Orientation to Studies in Book and Print Culture (Toronto: University of Toronto Press, 2006), 4-5.

62. See J. Shen-Miller et al, "Exceptional Seed Longevity and Robust Growth: Ancient Sacred Lotus from China," American Journal of Botany 82.11 (1995): 1367-80. 
ephemeral, or, at least to have had relatively short life-cycles in the eighteenth century, their afterlife now, in institutional archives, three hundred years on, qualifies this designation.

\section{Acknowledgements}

This essay is dedicated to Douglas D.C. Chambers, whose garden history scholarship and Stonyground garden in Walkerton, Ontario first sowed my interest in the bookish life of seeds. I also wish to thank the anonymous reviewers and editors at Lumen for their comments and suggestions. For their assistance in accessing collections, I am particularly grateful to Jacek Wajer and Ranee Prakash at the Natural History Museum, London, and to Isabelle Charmantier at the Linnean Society, London. 